\title{
Novel Insights on the Sustainable Wet Mode Fractionation of Black Soldier Fly Larvae (Hermetia illucens) into Lipids, Proteins and Chitin
}

\author{
Harish Karthikeyan Ravi ${ }^{1, *}$, Côme Guidou ${ }^{2}$, Jérôme Costil ${ }^{2}$, Christophe Trespeuch ${ }^{2}$, Farid Chemat ${ }^{1}$ (D) \\ and Maryline Abert Vian ${ }^{1, *(\mathbb{D})}$ \\ 1 GREEN Extraction Team, INRAE, UMR 408, Avignon University, 84000 Avignon, France; \\ farid.chemat@univ-avignon.fr \\ 2 Mutatec, 4 Rue Toussaint Flechaire, 84510 Caumont-sur-Durance, France; c.guidou@mutatec.com (C.G.); \\ j.costil@mutatec.com (J.C.); c.trespeuch@mutatec.com (C.T.) \\ * Correspondence: harish-karthikeyan.ravi@alumni.univ-avignon.fr (H.K.R.); \\ maryline.vian@univ-avignon.fr (M.A.V.)
}

check for updates

Citation: Ravi, H.K.; Guidou, C.; Costil, J.; Trespeuch, C.; Chemat, F.; Vian, M.A. Novel Insights on the Sustainable Wet Mode Fractionation of Black Soldier Fly Larvae (Hermetia illucens) into Lipids, Proteins and Chitin. Processes 2021, 9, 1888. https://doi.org/10.3390/pr9111888

Academic Editor: Olaniyi

Amos Fawole

Received: 20 September 2021

Accepted: 20 October 2021

Published: 22 October 2021

Publisher's Note: MDPI stays neutral with regard to jurisdictional claims in published maps and institutional affiliations.

Copyright: (c) 2021 by the authors. Licensee MDPI, Basel, Switzerland. This article is an open access article distributed under the terms and conditions of the Creative Commons Attribution (CC BY) license (https:// creativecommons.org/licenses/by/ $4.0 /)$.

\begin{abstract}
The black soldier fly larvae (BSFL) is a sustainable ingredient for feed applications, biofuels, composite materials and other biobased products. Processing BSFL to obtain lipid and protein fractions with enhanced functional properties as a suitable replacement for conventional feed ingredients has gained considerable momentum. In this regard, a novel and sustainable wet mode fractionation (WMF) scheme for BSFL was explored. Fresh BSFL were steam blanched and pulped to obtain BSFL juice and juice press cake. Subsequent treatment of BSFL juice employing homogenization or enzyme incubation and further centrifugation resulted in the obtention of four different BSFL fractions (Lipid-LF; Cream-CF; Aqueous-AF; and Solid-SF). Total energy consumption for a batch BSFL (500 g) WMF process was $0.321 \mathrm{kWh}$. Aqueous and solid fractions were the predominant constituents of BSFL juice. Lauric acid (44.52-49.49\%) and linoleic acid (19.12-20.12\%) were the primary fatty acids present in BSFL lipids. Lipid hydrolysis was observed in lipids belonging to the solid (free fatty acids > triacylglycerides) and cream fractions. Aqueous fraction proteins (ctrl) displayed superior emulsion stability and foam capacity than other treatments. Juice press cake retained $60 \%$ of the total chitin content and the rest, $40 \%$, was found in the solid fraction (ctrl). The material distribution of principal constituents in different fractions of the WMF process and amino acid profile was elucidated. Overall, the versatile WMF process proposed in this study involves simple unit operations to obtain functional ingredients from BSFL, which can be further explored by researchers and industry stakeholders.
\end{abstract}

Keywords: black soldier fly larvae; sustainable; wet mode fractionation; proteins; lipids; functional ingredients

\section{Introduction}

The black soldier fly (BSF; Hermetia illucens) is a saprophytic insect species hailed as the "crown jewel" of insects [1] for its inherent ability to facilitate nutrition upcycling of organic waste substrates and agrifood industrial byproducts into sustainable biomass for feed applications. Waste valorisation with BSF tackles two critical challenges, (i) serving as an effective tool for the bioconversion of waste materials into products of commercial interest, thereby (ii) generating an alternative feed ingredient that can replace conventional feed sources such as soybean and fish meal [2]. The inclusion of BSF for waste valorisation has a plethora of advantages. For example, BSF is an excellent tool for organic waste reduction, bioconversion, nutrition upcycling and establishing a circular economy. Among the myriad of applications that can be attributed to BSF, the most important trait is the "structured transformation of nutrients", wherein organic waste stream substrates with diverse micro- 
and macronutrients (varying amino and fatty acid profile) are converted to known highquality nutrients (protein-peptide, amino acid; lipid-fatty acid; and minerals) [3]. This ensures the retention, or rather the restoration, of nutrients (nutrient recapture) back again into the food chain that otherwise would have been lost in the downstream waste processing [4].

The European Union (EU), alone, imports 14 million tonnes of soybeans per year to meet the protein requirement of animals reared for meat (chicken, pigs and cattle) and milk production [5]. Insect meals, mainly black soldier fly larvae (BSFL) meal reared on wastes of vegetable origin or approved former foodstuffs, can be utilized to replace soybean meal, thereby reducing the reliance on oilseed crops grown for feed applications. Several studies have acknowledged and elucidated the feasibility of replacing (partial or complete) soybean or fish meals with BSFL meals without influencing or affecting the growth characteristics of the studied species [3,6-8]. Recently, the positive scientific opinion on the safety of dried yellow mealworm (Tenebrio molitor) as a novel food [9] by the EU regulatory body EFSA (European Food Safety Authority) is a significant boost to insect industry stakeholders and consumers.

The cornerstone of insect processing for feed applications is the fractionation method employed to obtain different fractions (proteins and lipids). In this regard, the dry mode fractionation of BSFL is relatively simple and can be efficiently executed on an industrial scale. Once the larvae reach the optimal stage for harvesting, they are separated from the frass (undigested substrate and insect faeces), and the primary unit operation is the devitalization technique or killing method [10]. Optionally, a cleaning method can be included to remove the debris and physical impurities adhering to the BSFL biomass. In the dry mode, the larvae are euthanized, dried, and pressed to obtain BSFL proteinrich pellets and crude BSFL oil. The drying of larvae and pressing at high temperatures to expel maximum oil denatures the protein and diminishes the functional properties of proteins in the pellet. Improvement in fractionation methods for optimum yield of the three prominent chemical constituents from BSFL (protein, fat and chitin) whilst maintaining their individual functionality and integrity is one of the intriguing challenges in BSFL processing [11]. Within the scope of wet mode fractionation, a mechanical process for sustainable production of BSF ingredients was published in which fresh larvae were directly fractionated [12].

Apart from the fractionation techniques, several research works have been undertaken to outline the processing techniques employed to retrieve chemical constituents of interest present in BSFL. For instance, Caligiani and others [11] discussed different extraction protocols, including chemical and enzyme-assisted extraction to recover pure fat (solventpetroleum ether), protein (Osborne fractionation and enzyme) and chitin fractions from BSF prepupae. A similar procedure for sequential extraction of lipids, protein and chitin was proposed [13]. In the latter study, lipids were extracted with petroleum ether, and the defatted flour was subjected to alkaline extraction $(\mathrm{pH}=11)$ and isoelectric precipitation $(\mathrm{pH}=4)$ for protein recovery, and the insoluble component emerging from this step was demineralized and deproteinated again to obtain chitin [13]. In our recent comprehensive review [3], a compilation of different individual unit operations along with an industrialscale purview for BSFL processing in both wet and dry mode fractionation was outlined. This work is an illustration of the wet mode fractionation of BSFL articulating the material distribution in this novel process.

The objective of this work is to reinforce the importance of wet mode refining of BSFL to obtain data points on the material distribution of various chemical constituents of commercial interest. This work reveals the simplicity of the unitary operations involved in wet mode BSFL fractionation with new insights comprising the energy consumption, amino acid distribution, antioxidant potential, fatty acid profile, lipid class, technofunctional properties (foam capacity and emulsion stability) of proteins along with their quality index and chitin distribution. The simplicity of the process allows it to be adopted as (i) a model 
for researchers working towards biorefining, cascading use and fractionation of BSFL and (ii) a blueprint for industrial-scale implementation.

\section{Materials and Methods}

\subsection{Solvents, Standards and Reagents}

Folin-Ciocalteu phenol reagent (Panreac Quimica S.L.U, Barcelona, Spain), sodium carbonate, 2,2-diphenyl-2-picryl-hydrazyl (DPPH), 6-hydroxy-2,5,7,8-tetramethyl chroman2-carboxylic acid (Trolox) and gallic acid were purchased from Sigma-Aldrich Chemie GMBH (Steinheim, Germany). Standards: DL- $\alpha$-palmitin, glyceryl 1,3-dipalmitate, glyceryl tripalmitate, palmitic acid, 2,2'-azino-bis (3-ethylbenzothiazoline-6-sulfonic acid), 2,4,6-tripyridyl-s-triazine, sodium acetate and Iron (III) chloride were purchased from Sigma-Aldrich (St. Louis, MO, USA). All solvents used for chromatography were of analytical grade.

\subsection{Wet Mode Fractionation Methodology}

Fresh BSF larvae reared on a proprietary mixture of fruit and vegetable wastes were provided by Mutatec (Caumont-sur-Durance, France), and the initial treatments such as washing, steam blanching and pulping were carried out within a span of $24 \mathrm{~h}$. Firstly, the fresh larvae were washed in a steady stream of tap water to remove debris adhering to its outer surface. The excess water was removed by placing it on a cheesecloth. Five hundred grams of the washed larvae were then steam blanched in a cooker at $95^{\circ} \mathrm{C}$ for $5 \mathrm{~min}$ and transferred immediately into the juice press (Qilive, Juice Extractor AJE328), which yields juice and juice press cake (JPC). This first batch was considered a priming step so that uniform output could be realized from the consecutive runs. The feeding rate into the juicer was $100 \mathrm{~g}$ of steam-blanched larvae/min. Several batches of steam-blanched BSFL $(n=10)$ were pulped, and the juice and press cake were pooled to have homogenous samples. Onethird of the juice obtained was labelled control ("Ctrl") and directly centrifuged (SIGMA $4-16 \mathrm{KS}$, Germany) at $8000 \mathrm{RPM}$ for 5 min once the temperature of the juice reached $45^{\circ} \mathrm{C}$. The rest of the juice was divided equally and subjected to homogenization and enzymatic treatment individually before centrifugation. Homogenization of the juice was carried out at 10,000 RPM for 5 min with a high-speed homogenizer (T-18, ULTRA-TURRAX, IKA, Staufen, Germany) and then centrifuged (labelled as " $\mathrm{Hg}$ "). The leftover juice was subjected to enzymatic treatment [12], wherein enzyme Alcalase ( $5 \% w / w$ of juice DM) was added to the juice to facilitate hydrolysis for $3 \mathrm{~h}$ at $60^{\circ} \mathrm{C}$ with gentle agitation. The hydrolysis was stopped by heating the juice-enzyme mixture to $90^{\circ} \mathrm{C}$ for $10 \mathrm{~min}$ and then centrifuged (labelled as "Et"). Energy consumption of unitary operations in the wet mode fractionation was monitored (Gilfort power meter $185 \mathrm{~V}-256 \mathrm{~V}$ ) and recorded.

Centrifugation of the juices (Ctrl, $\mathrm{Hg}$ and Et) yielded four distinct fractions, (i) lipid fraction, (ii) cream fraction, (iii) aqueous fraction and (iv) solid fraction, as shown in Figure 1. Proximate composition of each fraction after freeze-drying (aqueous and solid) or oven drying (lipid and cream) was evaluated. Moisture content was measured using a moisture analyser (OHAUS, MB35). Crude nitrogen content was estimated with a Kjeldahl system (Buchi speed digester, K-425). A nitrogen-to-protein conversion of 5.7 was used for all calculations [14]. Crude lipid content of the dried matrices was estimated based on Soxhlet extraction (Buchi extraction system, B-811) yields for which technical hexane was used as the solvent. Ash content was determined by placing the samples in a muffle furnace at $550{ }^{\circ} \mathrm{C}$ for $6 \mathrm{~h}$. 


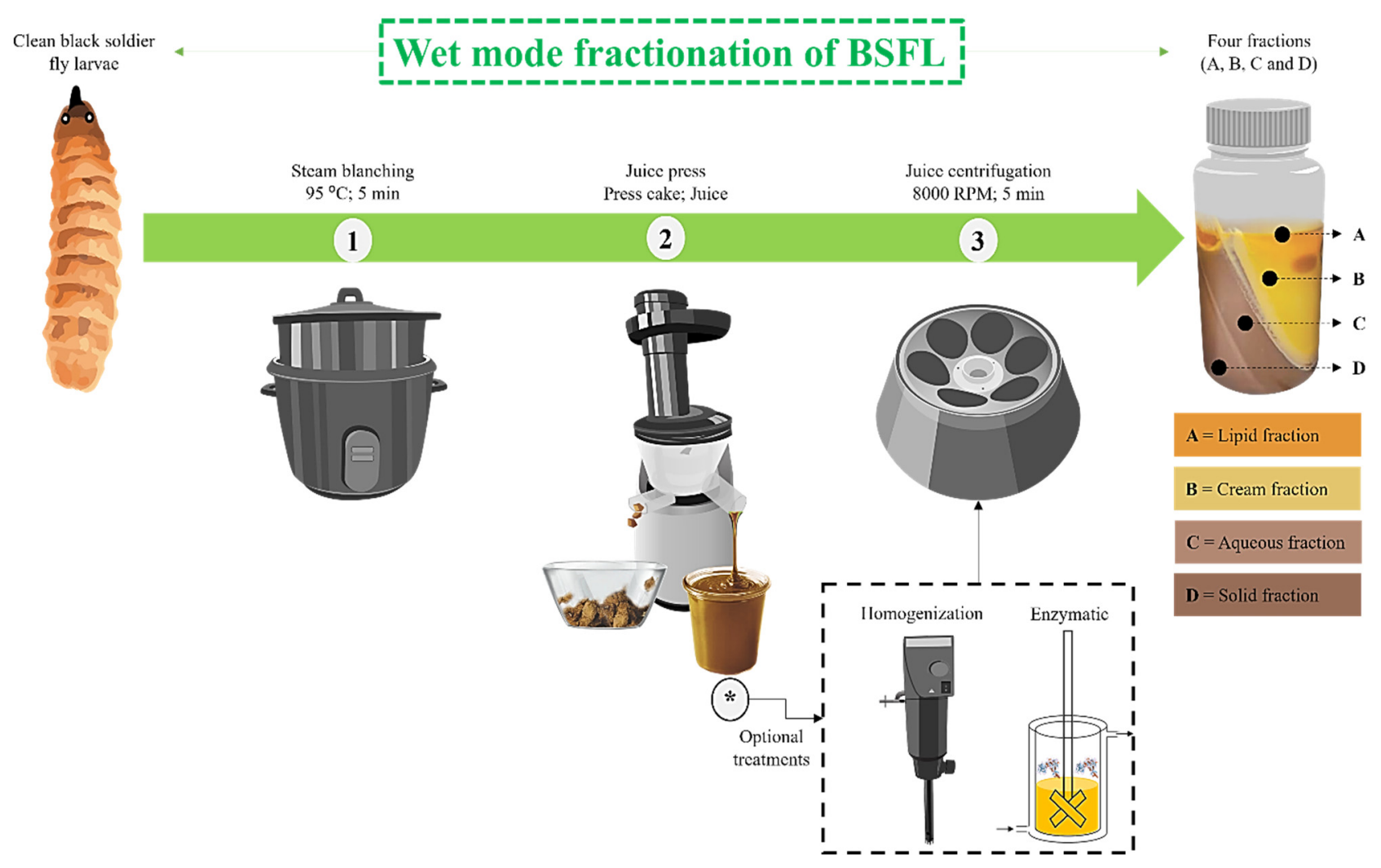

Figure 1. Graphical representation of the wet mode fractionation scheme.

\subsection{Fatty Acid Profile and Lipid Class Determination}

Transmethylation (acid-catalyst) was carried out on aliquots of crude lipid samples by reaction with methanolic sulfuric acid $(5 \%)$, and the mixture was heated for $90 \mathrm{~min}$ at $85^{\circ} \mathrm{C}$. Subsequently, once the mixture reached room temperature, $1.5 \mathrm{~mL}$ of sodium chloride $(0.9 \%$, $\mathrm{w} / \mathrm{v}$ ) and $1 \mathrm{~mL}$ of hexane (analytical grade) were added to facilitate phase separation. The mixture was mixed vigorously, and the hexane phase was recovered for fatty acid profile analysis with a gas chromatography system coupled with a flame ionization detector (GCFID). The GC-FID instrument (Agilent, Kyoto, Japan) was equipped with a BD-EN14103 capillary column $30 \mathrm{~m} \times 320 \mu \mathrm{m} \times 0.25 \mu \mathrm{m}$. The velocity of carrier gas (Helium) was maintained at $33 \mathrm{~cm} \mathrm{~s}^{-1}$. The sample injection volume was $2 \mu \mathrm{L}$ and was executed in a split mode (1:20 ratio). The back detector temperature was $260^{\circ} \mathrm{C}$. The oven temperature profile incrementally increased from $50{ }^{\circ} \mathrm{C}$ to $230{ }^{\circ} \mathrm{C}$ with varying holding times [15,16]. The relative quantity of different fatty acids was calculated based on the area under the curve and analysis was carried out in triplicates.

Lipid class distribution in oil extracted from different fractions was determined by high-performance thin-layer chromatography (HPTLC, CAMAG, Muttenz, Switzerland). Known quantities of lipid extracts along with corresponding standards were solubilized in chloroform and was spotted on an activated 60 F254 silica gel HPTLC plate (ATS 5 automatic TLC sampler). An eluent mixture with n-hexane/diethyl ether/glacial acetic acid in a ratio of 70:30:2 $(v / v / v)$ was used for plate development (ADC 2 automatic developing chamber). The developed plates were immersed in a revelation reagent (primuline) and scanned (TLC scanner 3) for identification and quantification of lipid class distribution in various fractions $[15,16]$.

\subsection{Protein Quality Parameters and Functional Properties}

The protein dispersibility index (PDI) and protein solubility (PS) of solid fractions (Ctrl, $\mathrm{Hg}$ and $\mathrm{Et}$ ) obtained from various treatments along with juice press cake (residue obtained from juice press) were calculated according to protocols indicated in the manual 
for soybean products in feed [17]. The PDI and PS values are indicative of the protein quality in BSFL meals. For instance, PDI measures the soluble protein in neutral water dispersed using a high-speed blender/homogenizer. At the same time, PS characterizes the protein solubility in alkaline conditions $(0.2 \%$ potassium hydroxide). The percentage ratio of water or alkaline dispersible protein to the total protein present in the samples were determined.

The oil binding capacity (OBC), foam capacity (FC) and emulsion stability (ES) of aqueous fractions obtained from different treatments were measured according to the BSFL specific method developed [18] to have comparable results with previously published data. The OBC was determined by mixing $500 \mathrm{mg}$ of each BSFL fraction with $10 \mathrm{~mL}$ rapeseed oil, and the powder-oil mixture was incubated for $30 \mathrm{~min}$ with occasional mixing. The samples were centrifuged (3000 RPM, $30 \mathrm{~min}$ ), and the unbound oil was removed. The weight differences were used to calculate the oil binding capacity and were expressed as $g$ of oil absorbed by $1 \mathrm{~g}$ of BSFL protein samples. Similarly, for ES, $500 \mathrm{mg}$ of protein samples were solubilized in $50 \mathrm{~mL} 0.1 \mathrm{M} \mathrm{NaCl}$, to which $50 \mathrm{~mL}$ of refined rapeseed oil was added, at 10,000 RPM using high shear homogenizer in order to obtain stable emulsions. The emulsions were transferred to a graduated cylinder, and after $15 \mathrm{~min}$ at room temperature, the volume of the aqueous phase and total volume were noted for ES calculation. For FC estimation, $750 \mathrm{mg}$ of aqueous BSFL fractions were solubilized in $25 \mathrm{~mL}$ deionized water and aerated with a homogenizer. The FC was calculated as the percentage ratio of difference between volume before and after aeration to the volume before aeration. All analyses were carried out in triplicate.

\subsection{Molecular Weight Distribution of Proteins}

Soluble proteins from various solid fractions and JPC were extracted using $0.1 \mathrm{M}$ citric acid-0.2 M disodium phosphate buffer ( $\mathrm{pH}$ 6) [14] and subjected to sodium dodecyl sulfate-polyacrylamide gel electrophoresis (SDS-PAGE) to visualize the protein distribution under reducing conditions. Equal volumes of protein samples and Laemmli sample buffer (65.8 mM Tris- $\mathrm{HCl}$, pH 6.8, 26.3\% glycerol, 2.1\% SDS, 0.01\% bromophenol blue, $5 \%$ 2-mercaptoethanol) were mixed, and $5 \mu \mathrm{L}$ of the mixture was loaded onto the TGX pre-cast gels (Bio-Rad mini-PROTEAN). After a $40 \mathrm{~min}$ run, the gel was carefully placed in $40 \%$ ethanol and $10 \%$ acetic acid solution for $10 \mathrm{~min}$ and washed with milli-Q water. Staining of the gel was performed with colloidal Coomassie solution for $6 \mathrm{~h}$ and then washed again for destaining. The gel image was captured using a CAMAG TLC visualizer, and ImageJ software was used for data processing.

\subsection{Amino Acid Composition and Chitin Quantitation}

The chitin content and amino acid composition of select BSFL fractions were measured by ion chromatography and high-pressure liquid chromatography, respectively, at IMPROVE SAS, France. Total glucosamine content was quantified after acid hydrolysis of the samples. The chitin content was then deduced by applying a conversion factor. The amino acid profile of select BSFL fractions was analysed as per ISO 13903:2005.

\subsection{Total Phenolics and Trolox Equivalent Antioxidant Capacity (TEAC) Assays}

Total polyphenol content in the aqueous fraction was determined by mixing $20 \mu \mathrm{L}$ of the sample with $80 \mu \mathrm{L}$ of $7.5 \%$ sodium carbonate and rapid addition of $100 \mu \mathrm{L}$ of FolinCiocalteu reagent (10-fold diluted) [19]. The absorbance of the mixture was monitored at $750 \mathrm{~nm}$ for $60 \mathrm{~min}$ using a SPECTRO star omega microplate reader equipped with a UV-vis spectrophotometer. Water and gallic acid were used as blank and standard, respectively. Results were expressed as gallic acid equivalents (GAE).

DPPH radical scavenging capacity (RSC) assay was performed according to BrandWilliams [20] method with slight modifications. Working DPPH solution $(0.5 \mathrm{mM})$ was freshly prepared in dimethyl sulfoxide (DMSO). Sample extracts and DPPH solution $50 \mu \mathrm{L}$ 
each was allowed to react, and absorbance was read at $520 \mathrm{~nm}$ for $60 \mathrm{~min}$. DMSO and trolox were used as blank and standard, respectively.

Another RSC assay using ABTS [2,2'-azino-bis(3-ethylbenzothiazoline-6-sulfonic acid)] radical cation was performed to determine the antioxidant potential of aqueous fraction extracts [21]. Freshly prepared ABTS stock solution was allowed to react with potassium persulfate overnight, and the stock solution was diluted with water until absorbance reached $0.7 \pm 0.02$ at $734 \mathrm{~nm}$. The sample extract $(30 \mu \mathrm{L})$ was allowed to react with a diluted ABTS solution. The degree of decolorization against blank (water) was monitored. Trolox was used for plotting the calibration curve.

Ferric reducing antioxidant power (FRAP) of aqueous fraction extracts was analysed according to the method proposed by Benzie and Strain [22]. Fresh FRAP reagent was prepared by mixing acetate buffer $(300 \mathrm{mM})$, 2,4.6-tripyridyl-s-triazine $(10 \mathrm{mM})$ solubilized in hydrochloric acid (40 mM) and Iron (III) chloride (20 mM) in a 10:1:1 ratio, respectively. The extracts $(100 \mu \mathrm{L})$ were added to $2.9 \mathrm{~mL}$ of FRAP reagent and allowed to react for $10 \mathrm{~min}$. Absorbance was recorded at $593 \mathrm{~nm}$ using a spectrophotometer (Biochrom, Libra S22, Cambridge, UK). Water was used as a blank, and trolox was used as standard. All analyses were carried out in triplicates.

\subsection{Statistical Analysis}

All analyses and corresponding data reported were performed in triplicates. The significance of the difference between mean values of different groups was analysed using analysis of variance (ANOVA - one way) post hoc test (Tukey's HSD), and $p$-value $(<0.05)$ was considered significant. Statistical data analysis was executed using XLSTAT v2019.1 statistical software (Addinsoft, New York, NY, USA).

\section{Results and Discussion}

\subsection{Energy Consumption and Material Distribution}

The three central unit operations involved in the wet mode fractionation (WMF) of BSFL are (i) steam blanching of the cleaned larvae, (ii) juice pressing and (iii) centrifugation of the juice to obtain various fractions. The energy consumption of the individual processes is summarized in Table 1 . The energy required to boil $1 \mathrm{~kg}$ of water was $0.169 \mathrm{kWh}$, and it was the most energy-intensive step. The fractionation was carried out in batch mode (500 $\mathrm{g}$ of fresh weight larvae) on a laboratory scale, and therefore, the energy utilization of each process is valid within these criteria. Overall energy consumption of the control treatment sums up to $0.321 \mathrm{kWh}$, highlighting the simplicity of this fractionation technique. Nevertheless, depending on the secondary processing of end products obtained through WMF, other unit operations such as an oven drying for solid fraction and juice press cake and spray drying for aqueous fraction can be incorporated.

Table 1. Energy consumption of unitary operations in batch BSFL wet mode fractionation.

\begin{tabular}{cc}
\hline Unit Operations & Energy Consumption (kWh) \\
\hline Boiling 1 L of water & 0.169 \\
Steam blanching 500 g of fresh larvae & 0.07 \\
Juice press-500 g of steam-blanched larvae & 0.008 \\
Homogenization (10 $\times$ 1000 RPM) & 0.005 \\
Centrifugation at 8000 RPM for 5 min & 0.069 \\
\hline
\end{tabular}

Unit kWh-Kilowatt-hours.

For instance, if industrial-scale feed production necessitates the addition of unique wet formulations, these fractions can be added as such, thereby forgoing any additional requirement of the drying processes. Recently, Azzollini and others [12] proposed a mechanical and enzyme-assisted fractionation process for the production of sustainable BSFL ingredients in which the washed larvae were immersed in hot water $\left(90{ }^{\circ} \mathrm{C}\right)$ and subjected to mechanical separation in order to obtain juice and a chitin-rich fraction (fibrous 
residue). In that research work, the mechanical separation was accomplished with a slow juicer, and the effect of sonication and enzyme incubation on the juice was elucidated. Meanwhile, in this study, a preliminary trial on a different batch of BSFL was carried out to examine the effect of various treatments such as microwave, homogenization, ultrasonication and enzymatic on the juice fraction (results not reported). The objective was to witness any physical improvement in the separability of different fractions post centrifugation. As ultrasonication and microwave displayed no physical improvement or distinction in the obtention of various fractions after centrifugation, only homogenization and enzymatic treatment were incorporated in this study.

The steam-blanched BSFL juice $(\mathrm{pH}=8.06 \pm 0.17$ ) is a complex mixture comprising fat, water, soluble protein, insoluble protein and cream. The relative distribution of each fraction after centrifugation with respect to the total weight of juice is shown in Figure 2. In the case of control and homogenization, the solid fraction was the largest individual constituent with $45.81 \pm 0.19 \%$ and $49.70 \pm 0.96 \%$, respectively. In the enzymatically treated juice sample, the aqueous fraction was the principal constituent, accounting for $52.59 \pm 0.54 \%$ of the total weight. An increase in the relative content of aqueous fraction in enzymatic treatment can be attributed to the hydrolysis of proteins and its subsequent solubilization in free water present in the juice. The centrifugation step in the industrial scale can be realized with decanters or tricanters for complete recovery of the various fractions obtainable by the WMF process [3]. Lipid fraction was the least constituent, making up $3.62 \pm 0.07 \%$ (Ctrl), $2.85 \pm 0.23 \%(\mathrm{Hg})$ and $7.79 \pm 0.39 \%$ (Et) of the total weight. During the proteolysis, the size of the protein aggregates is reduced, facilitating better lipid fractionation [12], which explains the substantial yield increase of lipid fraction in enzymatically treated BSFL juice (Et $>\mathrm{Ctrl}>\mathrm{Hg}$ ). Roughly around 73 to $75 \%$ of oil from the starting material of BSFL was lodged in the cream and lipid fractions, combined. The proximate composition of BSFL varies significantly depending on rearing conditions and substrate fed to the larvae [3]. Crude lipid content in the larvae and its fatty acid profile play a significant role in the retrievability of clear lipid and cream fractions. Their yields during WMF are dependent on the total availability of lipids. The total crude lipid content in BSFL batches used for this study was 30.49 $\pm 0.83 \%$ (DM), and this explains the lower yield of lipid fraction. A higher percentage of lipid fraction can be obtained from larvae rich in oil (>35\%). The significant difference in the relative proportion of solid, aqueous and lipid fractions of the enzymatic treatment compared to control and homogenization treatment could be attributed to the following: (i) proteolysis—solubilization of hydrolysed protein in the inherent water present in BSFL juice might explain the reduction in solid fraction and increase of aqueous fraction-and (ii) fat liquefaction-the residence time $(3 \mathrm{~h})$ of BSFL juice at higher temperature $\left(60^{\circ} \mathrm{C}\right)$ during enzyme incubation could have liquefied the fat resulting in an augmented yield of lipid fraction.

Fractionation of BSFL through mechanical separation (Angel juice press) of chitinrich biomass (BSFL exoskeleton) and insect juice was proposed [23]. Within the novel fractionation method that was patented, pulping was achieved with a juice press wherein the addition of water while pulping was recommended. The authors also found that the inclusion of organic acids improved the separation of different fractions that constitute BSFL juice [23]. 


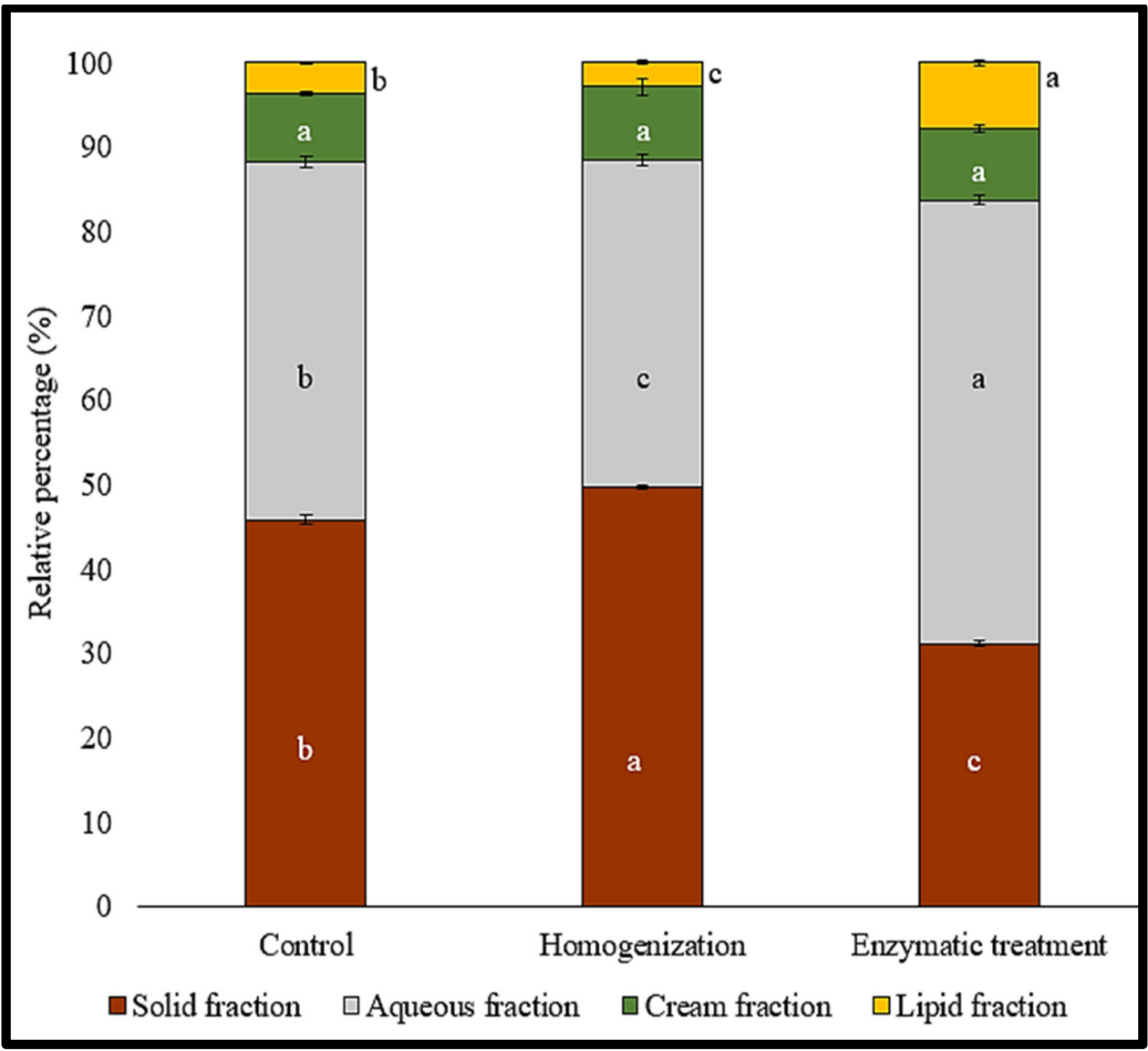

Figure 2. Relative distribution of different fractions in BSFL juice. Different letters in the individual fractions subjected to various treatments signify statistical differences $(p<0.05)$.

\subsection{Proximate Composition of BSFL Juice Fractions}

The proximate composition, namely lipid, protein, ash and moisture content of all fractions obtained by WMF treatments, are compiled in Figure 3. Veritably, lipid content in the cream fractions was $86.81 \pm 1.58 \%(\mathrm{Ctrl}), 76.59 \pm 1.44 \%(\mathrm{Hg})$ and $65.44 \pm 2.05 \%(\mathrm{Et})$. The entrapment of solid particles within the cream fraction contributed to a protein content of $7.21 \%, 6.31 \%$ and $15.89 \%$ for $\mathrm{Ctrl}, \mathrm{Hg}$ and Et treatments, respectively. Protein was the major nutrient present in the aqueous fractions, closely followed by carbohydrates and crude fibre, labelled as "Other" in Figure 3. Interestingly, the corresponding ash contents of Ctrl and $\mathrm{Hg}$ aqueous fractions were $14.92 \pm 0.36 \%$ and $14.24 \pm 0.29 \%$, suggesting that a significant quantity of minerals was present in them. This was not the case for $\mathrm{AF}_{\mathrm{Et}}$, which had an ash content of $7.89 \pm 0.29 \%$. The lipid content in solid fractions estimated by Soxhlet extraction with technical hexane as solvent revealed that not all lipids are amassed in the lipid and cream fraction. The lipid content in freeze-dried solid fractions were $12.39 \pm 0.58 \%(\mathrm{Ctrl}), 11.76 \pm 0.49 \%(\mathrm{Hg})$ and $8.59 \pm 0.35 \%(\mathrm{Et})$.

Protein was the primary chemical constituent in solid fractions, with almost $50 \%(w / w$, DM). Generally, in dry mode fractionation of BSFL, the larvae are dried and mechanically pressed to expel the oil, and a partially defatted BSFL protein meal with $8-10 \%$ of oil and $38-42 \%$ of protein is obtained [24]. In fact, the residual protein and oil content in the dried solid fraction is similar to the profile of partially defatted BSFL meal obtained by dry mode fractionation. Perhaps pulping of blanched BSFL with a better quality, high-shear juice press (counter-rotating or co-rotating screws) with adjustable settings could elicit better separation of oil into the lipid and cream fractions. Complete elimination of oil from BSFL meals can only be achieved with solvent defatting. Finally, the crude lipid content in dry juice press cake was $4.83 \pm 0.06 \%$. 


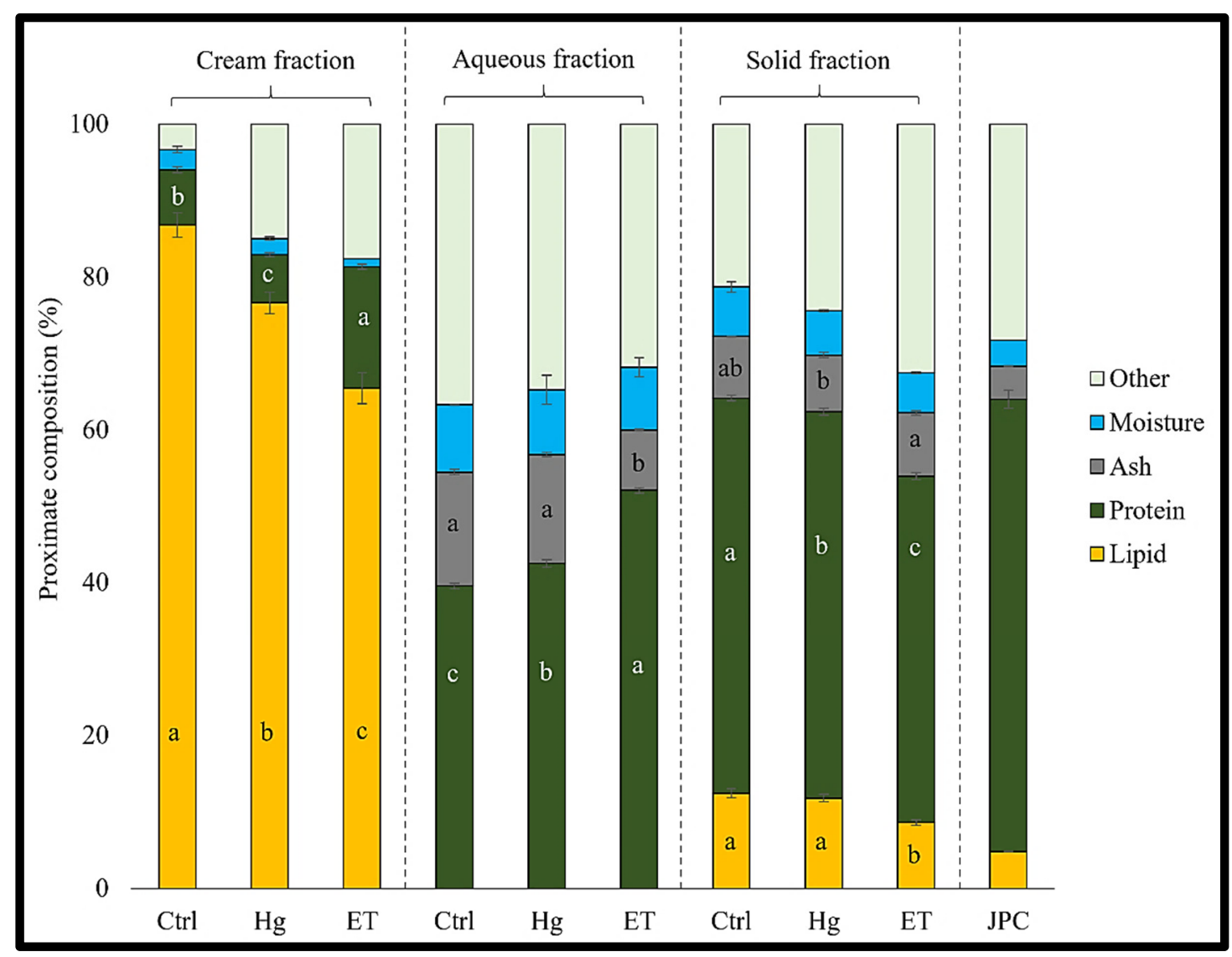

Figure 3. Proximate composition of various BSFL fractions subjected to different treatments. Different letters in individual fractions separated by dotted lines signify statistical difference $(p<0.05)$.

The material distribution and proximate composition analyses of BSFL are generic data that can be used to verify the feasibility of the processes for upscaling and comparison with existing conventional feed ingredients like soybean meal and fish meal. Meanwhile, though the wet mode fractionation process might be sustainable, analysing the implication of such processing on end-product quality (lipid and protein) is crucial and of paramount importance for insect processors and research groups. The following results are a few quality indicators of BSFL ingredients obtained with the WMF process.

\subsection{Fatty Acid Profile and Lipid Class Constituents}

The relative distribution of fatty acid profile across all fractions analysed was relatively homogenous (Table 2). Lauric acid (C12) was the major fatty acid ranging from $44.93 \%$ $\left(\mathrm{CF}_{\mathrm{Et}}\right)$ to $49.49 \%\left(\mathrm{SF}_{\mathrm{Et}}\right)$ and followed by palmitic acid $(\mathrm{C} 16)$ ranging from $13.77 \%\left(\mathrm{LF}_{\mathrm{Ctrl}}\right)$ to $17.22 \%\left(\mathrm{SF}_{\mathrm{Et}}\right)$ belonging to saturated fatty acids. The mean cumulative relative content of saturated fatty acids among the fractions was $66.79 \%$, making up two-thirds of the fatty acid profile. Linoleic (C18:2n6) and linolenic (C18:3n3) acids were the primary polyunsaturated fatty acids, corresponding to almost $20.11 \%$ of the total fatty acids. Oleic acid (C18:1n9) was the primary monounsaturated fatty acid. The fatty acid profile of the BSFL oil can be manipulated by altering its substrate composition [3]. In a recent study [25], the commercial chicken feed was altered with increasing quantities of rape cake and flax cake, and the researchers found that the saturated fatty acid content in BSFL oil can be reduced from $76 \%$ to $56 \%$. Incorporating flax cake in the substrate culminated in the increase of essential $\omega 3$ fatty acid ( $\alpha$-linolenic acid) from $0.7 \%$ to $15 \%$, making it an attractive ingredient for fish feed. 
Table 2. Fatty acid profile of different BSFL fractions.

\begin{tabular}{|c|c|c|c|c|c|c|c|c|c|c|c|}
\hline Fatty Acids (\%)/Sample ID & BSFL $_{S B F D}$ & $\mathbf{L F}_{\mathrm{Ctrl}}$ & $\mathrm{LF}_{\mathrm{Hg}}$ & $\mathbf{L F}_{\mathrm{Et}}$ & $\mathrm{CF}_{\mathrm{Ctrl}}$ & $\mathrm{CF}_{\mathrm{Hg}}$ & $\mathrm{CF}_{\mathrm{Et}}$ & $\mathrm{SF}_{\mathrm{Ctrl}}$ & $\mathrm{SF}_{\mathrm{Hg}}$ & $\mathrm{SF}_{\mathrm{Et}}$ & JPC \\
\hline $\mathrm{C} 10$ & 1.12 & 1.25 & 1.20 & 1.16 & 1.18 & 1.27 & 1.20 & 1.35 & 1.33 & 1.31 & 1.27 \\
\hline $\mathrm{C} 12$ & 44.52 & 47.61 & 46.78 & 46.28 & 46.62 & 47.42 & 44.93 & 48.26 & 47.88 & 49.49 & 49.09 \\
\hline $\mathrm{C} 14$ & 3.96 & 3.12 & 3.34 & 3.01 & 2.42 & 2.05 & 3.39 & 0.78 & 1.15 & 1.29 & 2.16 \\
\hline $\mathrm{C} 17$ & 0.23 & 0.18 & 0.18 & 0.20 & 0.21 & 0.17 & 0.22 & 0.18 & 0.15 & 0.17 & 0.13 \\
\hline $\mathrm{C} 20$ & 0.11 & 0.22 & 0.24 & 0.32 & 0.32 & 0.32 & 0.33 & 1.22 & 0.56 & 0.41 & 0.15 \\
\hline$\Sigma$ Saturated fatty acids & 64.49 & 66.14 & 65.75 & 65.85 & 66.61 & 66.18 & 65.13 & 68.19 & 65.77 & 69.89 & 68.41 \\
\hline $\mathrm{C} 16: 1$ & 2.13 & 2.17 & 2.16 & 2.19 & 2.25 & 2.39 & 2.16 & 1.30 & 2.54 & 1.20 & 1.13 \\
\hline$\Sigma$ Monounsaturated fatty acids & 13.38 & 12.10 & 12.53 & 12.61 & 12.43 & 12.57 & 13.93 & 10.21 & 11.83 & 9.44 & 10.76 \\
\hline C18:2n6 & 19.81 & 19.72 & 19.86 & 19.75 & 19.80 & 20.12 & 19.28 & 19.57 & 20.63 & 19.12 & 19.39 \\
\hline $\mathrm{C} 18: 3 \mathrm{n} 3$ & 1.01 & 0.87 & 0.81 & 0.77 & 0.25 & 0.14 & 0.54 & 0.10 & 0.12 & 0.14 & 0.09 \\
\hline$\Sigma$ Polyunsaturated fatty acids & 20.82 & 20.60 & 20.67 & 20.52 & 20.05 & 20.26 & 19.82 & 19.67 & 20.75 & 19.26 & 19.49 \\
\hline Other fatty acids & 1.30 & 1.17 & 1.05 & 1.02 & 0.91 & 0.99 & 1.12 & 1.92 & 1.65 & 1.41 & 1.34 \\
\hline
\end{tabular}

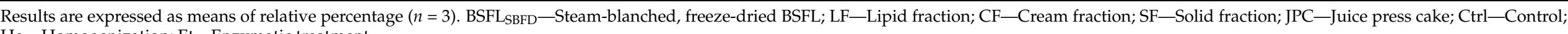
$\mathrm{Hg}-$ Homogenization; Et—Enzymatic treatment. 
Replacing soybean oil with dietary black soldier fly oil enriched with n-3 highly unsaturated fatty acids positively influenced the performance and health status of juvenile mirror carp [26]. Thus, both partially defatted BSFL meal and BSFL oil might be suitable replacements for conventional feed ingredients, and their incorporation in food-feed systems can alleviate the exploitation of agricultural and fish stocks.

Lipid class analysis gives insight into the distribution of lipid components such as triacylglycerols (TAG), diacylglycerols (DAG), monoacylglycerols (MAG) and free fatty acids (FFA) in the lipid samples. In the case of BSFL processing, it has been clearly established that the killing method greatly influences the lipid class constituents $[10,27,28]$. Freezing of larvae without any thermal pretreatment results in lipolysis wherein TAG are hydrolysed into FFA, DAG and MAG. A recent study on the wet extraction of lipids from fresh BSFL with 2-methyl tetrahydrofuran as solvent was proposed [29]. The study, too, found similar traits where TAG hydrolysis could not be avoided, even with solvent extraction in a wet phase. As a matter of fact, as of now, blanching as thermal treatment has been proposed as a viable solution to avoid lipolysis phenomenon in the oil fraction, which is why steam blanching was chosen as a preferred devitalization technique in this study. Steam blanching might be a better alternative to conventional blanching, as the latter might result in loss of protein when the larvae are immersed in hot water [12,28]. The lipid classes of various fractions obtained by WMF is shown in Figure 4.

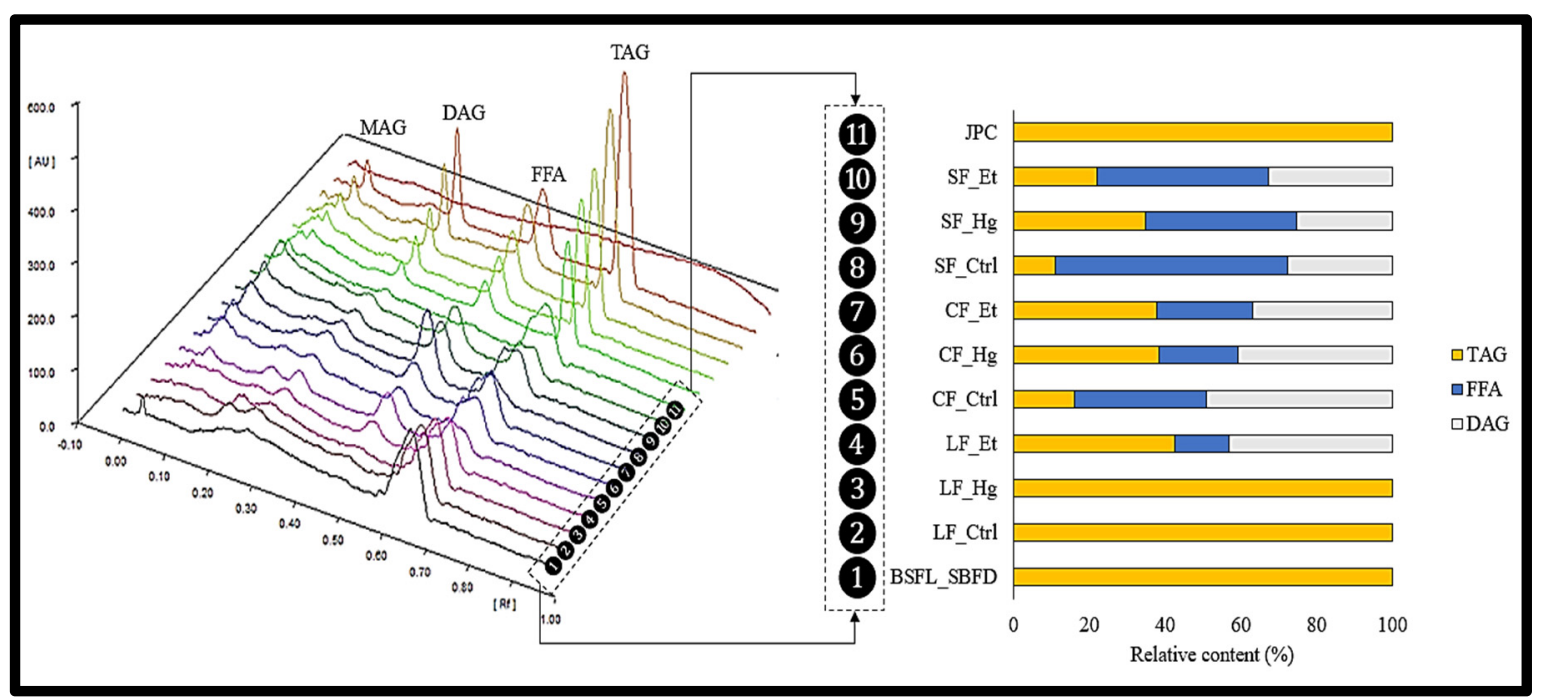

Figure 4. Lipid class composition of various BSFL fractions. BSFL_SBFD—Steam-blanched, freeze-dried; LF-Lipid fraction; $\mathrm{CF}$-Cream fraction; SF-Solid fraction; JPC—Juice press cake; Ctrl-Control; Hg-Homogenization; Et-Enzymatic treatment; TAG—Triacylglycerols; FFA—Free fatty acids; DAG—Diacylglycerols; MAG—Monoacylglycerols.

Lipid hydrolysis was observed in BSFL oil retrieved from all the fractions except for lipid fraction $\mathrm{Ctrl}$ and $\mathrm{Hg}$ treatment. A severe degree of lipid hydrolysis was found in oils extracted from solid fractions belonging to all treatments. Lipid fraction (Ctrl) had $100 \%$ TAG, suggesting that neither blanching nor juice press contributed to the lipolysis. If either of these unit operations did stimulate hydrolysis, it would have reflected in the oil profile of lipid fraction, as well. The fact that oil extracted from juice press cake also had $100 \%$ TAG supports this theory. During enzymatic treatment, the juice was incubated with proteolytic enzyme, which, inadvertently, might hydrolyse lipids. The exposure of juice (oil-water system) to high temperature during the enzymatic treatment could have also allowed the free water in the juice phase to hydrolyse TAG into FFA and DAG. The reason behind hydrolysis observed in solid and cream fractions could have also originated during analytical fraction (high moisture content in the matrix) or during storage. Solid fractions were freeze-dried, and the residual moisture content before Soxhlet extraction (hexane) was around 6\%, which could have triggered lipid hydrolysis. 
Ironically, homogenization and enzymatic treatment mitigated the degree of lipolysis in solid and cream fractions to an extent when compared to that of control. The relative content of TAG in $\mathrm{CF}_{\mathrm{Hg}}(38.31 \%)$ was greater than $\mathrm{CF}_{\mathrm{Ctrl}}(16.24 \%)$, analogous to the TAG concentration in $\mathrm{SF}_{\mathrm{Hg}}(34.80 \%)$, which was higher than $\mathrm{SF}_{\mathrm{Ctrl}}(11.16 \%)$. To address the uncertainties regarding lipolysis, more data and focused research on this aspect are required to pinpoint the exact mechanism liable for the propagation of lipolysis in these fractions. When partially defatted BSFL meal such as the solid fractions (WMF process) possess a higher content of free fatty acids in their lipid component, it might lead to accelerated oil oxidation and rancidity, compromising the shelf-life stability of the end product.

Other solvents such as aqueous ethyl acetate [30], petroleum ether, ethanol and acetone [31] have been tested for degreasing dry BSFL. In one study, the authors [30] found that ethyl acetate with $10 \%$ water displayed a high degreasing rate $(29.04 \%)$, and the biobased solvent did not affect the nutritional value of the defatted meal. The utilization of ethanol as solvent for defatting resulted in higher larval crude oil yield when compared to petroleum ether and acetone. In our previous study, we discussed the potentiality of 2-methyl tetrahydrofuran replacing hexane for the delipidification of BSFL. Alternative biobased solvents such as 2-methyl tetrahydrofuran, ethanol and ethyl acetate seem to be potential alternatives for conventional solvents [28-31]. Yet, several practical challenges exist for the industrial-scale implementation of such solvents, namely cost of solvent, energy requirement, infrastructure availability, scientific data of solvent and its interaction with biomass.

\subsection{Molecular Weight Distribution of Proteins}

Visualization of protein distribution in different fractions was realized, employing gel electrophoresis (Figure 5). Numerous protein bands were detected in the aqueous fractions ( $\mathrm{Ctrl}$ and $\mathrm{Hg}$ ) compared to the soluble proteins of solid fraction. Complementary to previously communicated results [28,32], the most abundant proteins were close to $75 \mathrm{kDa}$ and $15 \mathrm{kDa}$. Soluble proteins from juice press cake (Lane "a") had abundant proteins at $17.5 \mathrm{kDa}$ and between 10 and $15 \mathrm{kDa}$, signifying a difference in extractable proteins from different fractions. Aqueous fraction proteins subjected to enzymatic treatment showed no significant bands above $5 \mathrm{kDa}$, which implies $\mathrm{AF}_{\mathrm{Et}}$ peptides were hydrolysed entirely. The protein bands belonging to $\mathrm{SF}_{\mathrm{Et}}$ were feeble (Lane " $\mathrm{e}$ "), possibly due to the presence of more insoluble proteins in that particular fraction. Homogenization treatment could have denatured proteins, as more protein bands were seen in $\mathrm{SF}_{\mathrm{Ctrl}}$. Rabani and others [33], in their proteomic study of BSFL, found comparable protein bands at $75 \mathrm{kDa}$. Similar results were outlined by [34], where proteins extracted with buffers from BSFL meal had similar molecular weight distribution.

The most abundant protein group in BSFL and their protein hydrolysates belong to the muscle proteins (58\%). Moreover, 19\% of the peptides identified in BSF protein extracts corresponds to cuticular proteins, and $5 \%$ of the peptides were ascribed to enzyme proteins in a recent study [35]. However, differences were evident in the molecular weight distribution of proteins among the juice press cake (Lane "a"), aqueous (Lane "c-d") and solid (Lane " $f-g$ ") fractions. More pertinent data on the functionality of BSFL proteins obtained from different fractions are required to explain the distinction observed, but the protein quality results from this study indicate that the aqueous fraction comprises the water-soluble proteins, followed by solid fractions and, finally, juice press cake, which displayed poor protein solubility, probably due to the presence of water-insoluble cuticular proteins. 


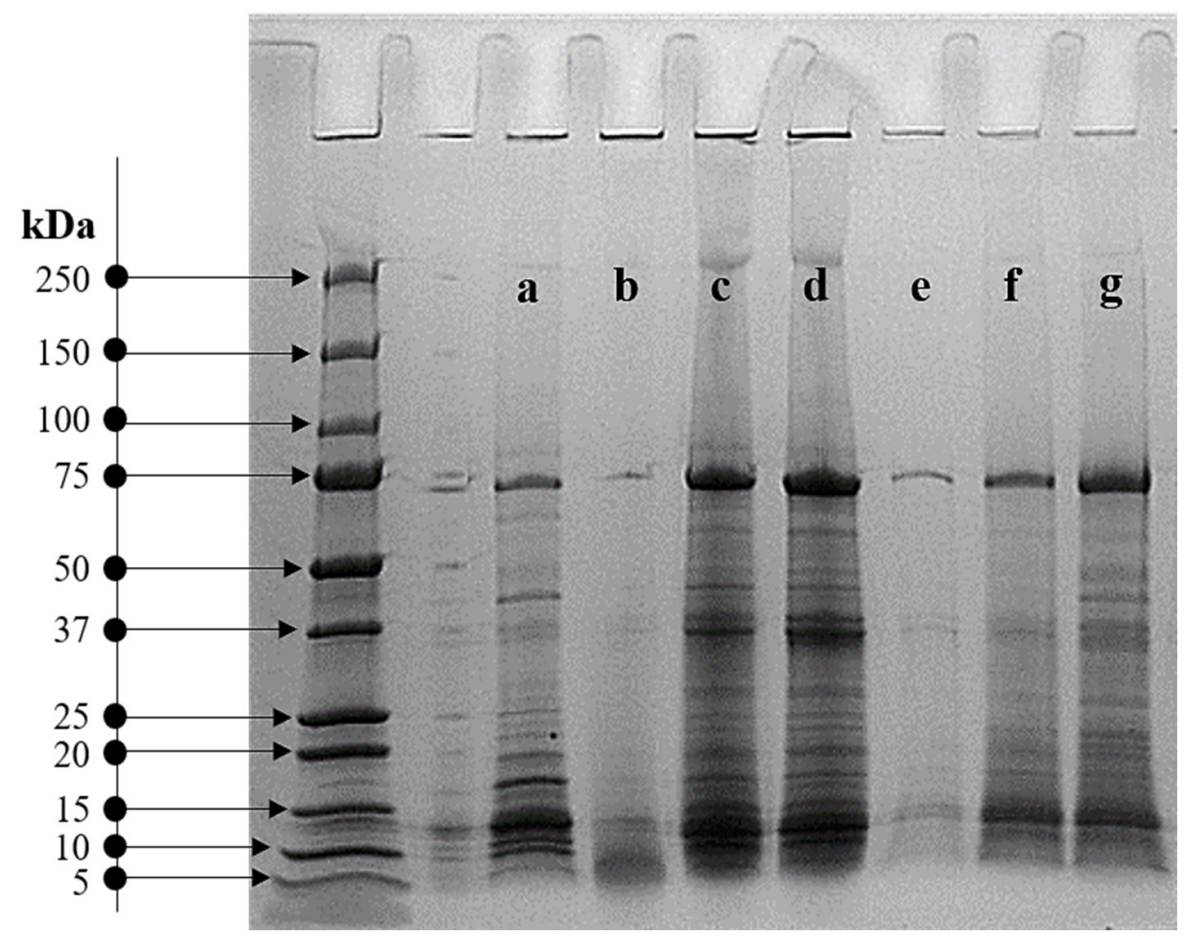

Figure 5. The molecular weight distribution of proteins belonging to different fractions obtained by WMF process. (a) JPC; (b) $\mathrm{AF}_{\mathrm{Et}} ;$ (c) $\mathrm{AF}_{\mathrm{Hg}} ;$ (d) $\mathrm{AF}_{\mathrm{Ctrl}}$; (e) $\mathrm{SF}_{\mathrm{Et}}$; (f) $\mathrm{SF}_{\mathrm{Hg}}$; (g) $\mathrm{SF}_{\mathrm{Ctrl}}$. JPC-Juice press cake; $\mathrm{AF}$-Aqueous fraction; $\mathrm{SF}-$ Solid fraction; Ctrl-Control; $\mathrm{Hg}-$ Homogenization; Et-Enzymatic treatment.

\subsection{Protein Functional Properties and Quality Parameters}

Functional properties such as emulsion stability (ES), foam capacity (FC) and oilbinding capacity $(\mathrm{OBC})$ of aqueous fraction proteins were elucidated (Figure 6). Only aqueous fractions were considered, as they represent the water-soluble proteins recovered from each treatment. As further extraction steps would be required for analysing the functional properties of solid fraction and juice press cake proteins, they were not included in these analyses (ES and FC). Instead, parameters such as protein dispersibility index (PDI) and protein solubility (PS) were estimated to characterize their protein quality.
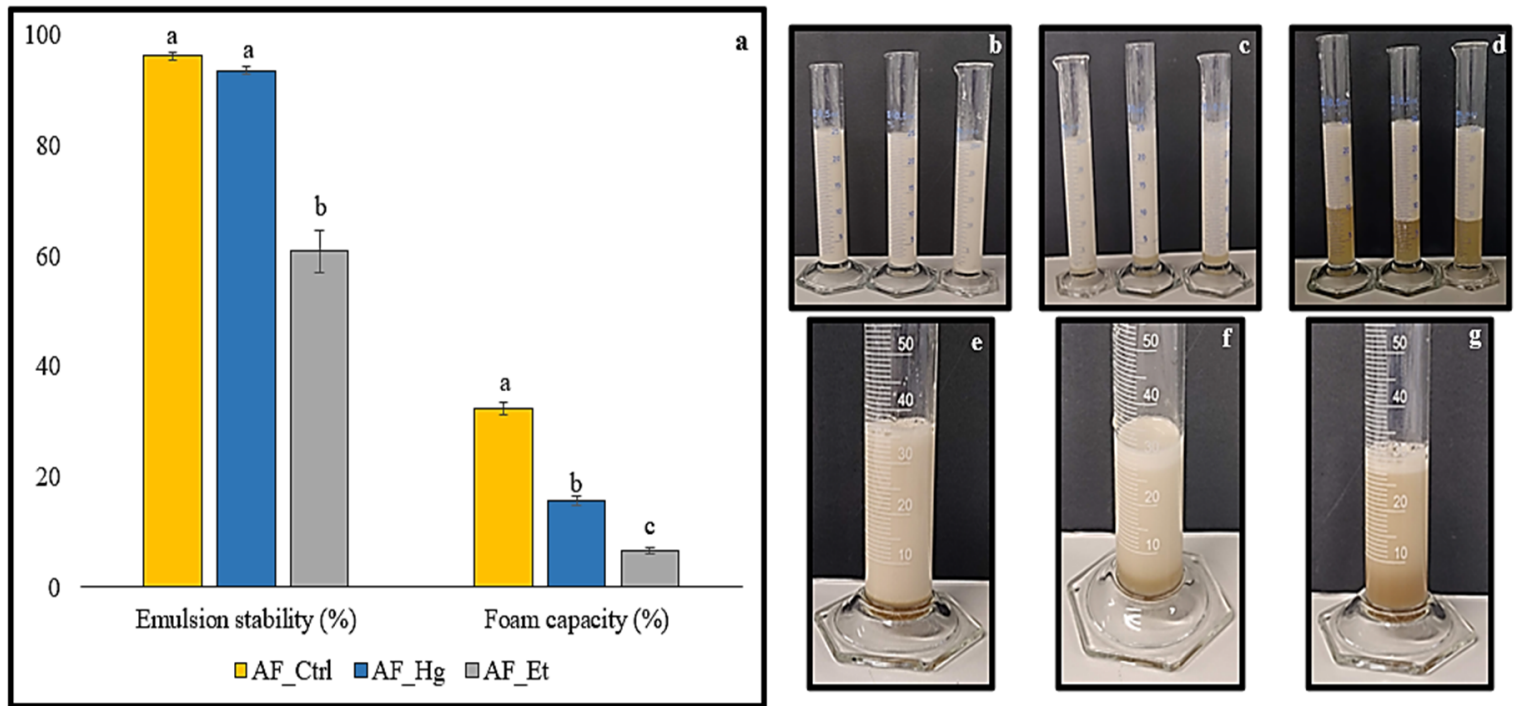

Figure 6. (a) Functional properties of aqueous fraction BSFL proteins. (b-d) Emulsion stability of AF proteins ((b) $\mathrm{AF}_{\mathrm{Ctrl}}$; (c) $\left.\mathrm{AF}_{\mathrm{Hg}} ;(\mathbf{d}) \mathrm{AF}_{\mathrm{Et}}\right) ;(\mathbf{e}-\mathbf{g})$ foam capacity of $\mathrm{AF}$ proteins $\left((\mathbf{e}) \mathrm{AF}_{\mathrm{Ctrl}} ;(\mathbf{f}) \mathrm{AF}_{\mathrm{Hg}} ;(\mathrm{g}) \mathrm{AF}_{\mathrm{Et}}\right)$. Different letters above individual bars signify statistical difference $(p<0.05)$. 
The oil absorption or binding capacity of protein products is an indicator to enhance the taste, deep processing and flavour [36], which ensures palatability of feed ingredients. The OBC of aqueous fraction proteins of Ctrl, $\mathrm{Hg}$ and Et were $2.51 \pm 0.1,2.40 \pm 0.12$ and $2.12 \pm 0.09 \mathrm{~g}$ of oil $/ \mathrm{g}$ DM. Enzymatic treatments of migratory locust (ML) protein led to a rise in the $\mathrm{OBC}$ of corresponding protein hydrolysates. Yet, the maximum value of $2.33 \mathrm{~g}$ oil/g DM reported for ML was less than the OBC displayed by the $\mathrm{AF}_{\mathrm{Ctrl}}$ BSFL fraction. The increase of OBC in ML hydrolysates were ascribed to the exposure of hydrophobic residues post enzymatic treatment [37]. Evidently, this phenomenon was observed in solid fraction proteins (Table 3), as the aqueous fraction constitutes only hydrophilic protein hydrolysates. The OBC for BSFL protein concentrate, when compared to protein hydrolysates, did not vary significantly, but the values reported were almost two times higher ( $4 \mathrm{~g}$ oil/g DM) in a recent study [18]. The OBC of protein concentrates and flours prepared from other insect species such as Tenebrio molitor, Gryllodes sigillatus and Schisocerca gregaria were within the range of 1.7 to $3.3 \mathrm{~g}$ oil $/ \mathrm{g}$ DM [38].

Table 3. Protein quality parameters of BSFL solid fractions.

\begin{tabular}{ccccc}
\hline Sample ID & Crude Protein (\%) & PDI (\%) & PS (\%) & OBC (g Oil/g DM) \\
\hline $\mathrm{SF}_{\mathrm{Ctrl}}$ & $51.75 \pm 0.36$ & $32.41 \pm 1.46^{\mathrm{b}}$ & $68.25 \pm 1.41^{\mathrm{b}}$ & $2.69^{\mathrm{c}} \pm 0.15^{\mathrm{a}}$ \\
$\mathrm{SF}_{\mathrm{Hg}}$ & $50.6 \pm 0.48$ & $27.44 \pm 1.21^{\mathrm{c}}$ & $63.68 \pm 1.31^{\mathrm{c}}$ & $2.68^{\mathrm{a}} \pm 0.05^{\mathrm{a}}$ \\
$\mathrm{SF}_{\mathrm{Et}}$ & $45.32 \pm 0.43$ & $76.68 \pm 1.56^{\mathrm{a}}$ & $77.05 \pm 1.56^{\mathrm{a}}$ & $2.8 \pm 0.04^{\mathrm{a}}$ \\
$\mathrm{JPC}$ & $59.15 \pm 1.16$ & $18.51 \pm 2.57$ & $76.94 \pm 2.21$ & $5.91 \pm 0.05$ \\
\hline
\end{tabular}

Results are expressed as mean \pm standard deviation $(n=3)$. SF-Solid fraction; Ctrl—Control; Hg-Homogenization; Et_Enzymatic treatment; JPC—Juice press cake; PDI-Protein dispersibility index; PS—Protein solubility in $0.2 \%$ potassium hydroxide; OBC-Oil binding capacity. Values with different superscript letters within the column signify statistical difference $(p<0.05)$.

The emulsion stability of a protein is its inherent ability to participate in emulsion formation and stabilization of the newly formed emulsion system. The ES of $\mathrm{AF}_{\mathrm{Ctrl}}$ and $\mathrm{AF}_{\mathrm{Hg}}$ were $96.23 \pm 0.6 \%$ and $93.61 \pm 0.75 \%$, respectively. A drastic reduction in $\mathrm{ES}$ of $\mathrm{AF}_{\mathrm{Et}}$ $(60.93 \pm 3.84 \%)$ was noticed, which is a typical characteristic exhibited by extensively enzymatically hydrolysed proteins due to excessive protein degradation negatively affecting the interfacial absorptivity and molecular rearrangement at the surface $[37,39]$. The results were analogous to the data reported by Batish et al. [18]. Perhaps a stringent method of ES determination proposed for edible insects could be adapted for future functionality investigation to obtain comparable results [38]. The foam capacity of $\mathrm{AF}_{\mathrm{Ctrl}}$ was superior to $\mathrm{AF}_{\mathrm{Hg}}$ and $\mathrm{AF}_{\mathrm{Et}}$ (Figure 6a), with a value of $32.46 \pm 1.19 \%$, which was well within the observed range for whole protein flours belonging to other edible insect species [38]. As anticipated, the FS of $\mathrm{AF}_{\mathrm{Et}}$ was considerably lower $(6.72 \pm 0.52 \%)$. None of the aqueous fractions exhibited foam stability. Foams with half-time less than $6 \mathrm{~min}$ are not considered stable [40]. Foam formation is influenced by several factors including surface hydrophobicity, localization of hydrophobic amino acid residues on the protein surface and presence of carbohydrates and lipids [38]. Aqueous fractions do have a higher quantity of soluble sugars and carbohydrates in them (Figure 3).

Protein quality parameters such as PDI and PS are readily available indicators that feed manufacturers rely on for the selection of appropriate ingredients. These parameters suggest the extent of thermal degradation of proteins in soybean meal. Highest PDI (77\%) and PS (77\%) were exhibited by the $\mathrm{SF}_{\mathrm{Et}}$ fraction (Table 3), which highlights that not all proteins were solubilized in the aqueous phase of the juice. As previously established, for juice, being a complex soluble protein-water-oil-insoluble protein interface, there could be hindrances in the solubilization of proteins. Nevertheless, easy dispersibility of proteins in water indicates better bioavailability when incorporated in feed formulations.

The PDI values of $\mathrm{SF}_{\mathrm{Ctrl}}(32 \%)$ and $\mathrm{SF}_{\mathrm{Hg}}(27 \%)$ were similar to results previously reported for various BSFL protein meals and flours $[10,28]$. The lowest PDI belonged to dry juice press cake $(18.5 \%)$, even with the highest crude protein $(59 \%)$, signifying the presence 
of water-insoluble proteins. The OBC of solid fractions was identical to that of aqueous fraction samples.

A concise review of edible insect proteins and their functional properties was published recently [41]. Insect proteins are a plausible alternative to plant proteins for food and feed applications [41]. There are many favourable attributes such as high nutritional value, better digestibility of proteins, good essential amino acid profile and lesser environmental impacts, while production makes them an ideal replacement for conventional protein sources. The recent EFSAs' positive opinion paper on dry Tenebrio molitor for human consumption [9] is a landmark recognition for insect inclusion in food and approval for other promising insect species larvae (such as black soldier fly) can be anticipated in the near future.

\subsection{Amino Acid Distribution in Wet Mode BSFL Fractions}

The amino acid profile of the juice press fraction was different from the aqueous and solid fractions (Table 4).

Table 4. Amino acid distribution in BSFL fractions.

\begin{tabular}{|c|c|c|c|c|c|c|c|}
\hline Amino Acid/Sample & JPC & $\mathrm{SF}_{\mathrm{Ctrl}}$ & $\mathrm{AF}_{\mathrm{Ctrl}}$ & $\mathrm{SF}_{\mathrm{Et}}$ & $\mathbf{A F}_{\mathrm{Et}}$ & SBM \# & $\mathbf{F M}^{\#}$ \\
\hline Alanine & 6.15 & 2.80 & 2.25 & 2.22 & 3.10 & 2.04 & 4.03 \\
\hline Arginine * & 2.81 & 2.97 & 1.77 & 2.19 & 2.08 & 3.53 & 3.82 \\
\hline Aspartic acid & 4.65 & 6.51 & 3.55 & 5.22 & 6.39 & 5.52 & 5.79 \\
\hline Cysteine + Cystine & 0.41 & 0.68 & 0.40 & 0.56 & 0.53 & 0.77 & 0.6 \\
\hline Glutamic acid & 5.82 & 6.51 & 7.05 & 5.46 & 8.07 & 8.56 & 8.3 \\
\hline Glycine & 4.50 & 2.55 & 1.78 & 2.15 & 2.66 & 2 & 4.8 \\
\hline Histidine * & 2.04 & 1.88 & 2.33 & 1.62 & 1.92 & 1.26 & 1.45 \\
\hline Isoleucine * & 2.64 & 2.63 & 1.03 & 2.21 & 2.30 & 2.26 & 2.66 \\
\hline Leucine * & 4.59 & 4.22 & 1.45 & 3.45 & 3.53 & 3.78 & 4.61 \\
\hline Lysine * & 3.15 & 4.52 & 1.85 & 3.44 & 4.11 & 3.13 & 4.98 \\
\hline Methionine * & 0.73 & 1.39 & 0.33 & 1.18 & 1.15 & 0.68 & 1.8 \\
\hline Phenylalanine * & 2.10 & 2.94 & 1.04 & 2.59 & 2.29 & 2.4 & 2.43 \\
\hline Proline & 7.44 & 2.42 & 1.29 & 2.10 & 2.22 & 2.21 & 2.7 \\
\hline Serine & 3.26 & 2.18 & 1.14 & 1.74 & 2.13 & 2.06 & 2.1 \\
\hline Threonine * & 2.40 & 2.47 & 1.13 & 1.95 & 2.33 & 1.82 & 2.49 \\
\hline Tryptophan * & 1.14 & 1.09 & 0.57 & 0.93 & 0.79 & 0.7 & 1.95 \\
\hline Tyrosine & 4.88 & 3.54 & 1.59 & 2.83 & 3.04 & 1.78 & 3.14 \\
\hline Valine * & 5.16 & 2.97 & 1.42 & 2.48 & 2.79 & 2.4 & 4.03 \\
\hline TAA & 63.88 & 54.27 & 31.96 & 44.31 & 51.42 & 46.9 & 61.68 \\
\hline$\Sigma$ EAA & 26.76 & 27.08 & 12.91 & 22.04 & 23.29 & 21.96 & 30.22 \\
\hline$\%$ EAA/TAA & 41.90 & 49.90 & 40.39 & 49.73 & 45.28 & 46.82 & 48.99 \\
\hline
\end{tabular}

TAA-Total amino acid; * EAA-Essential amino acid; JPC-Juice press cake; SF-Solid fraction; AF-Aqueous fraction; SBM-Soybean meal; FM-Fish meal; Ctrl-Control; Et-Enzymatic treatment; ${ }^{\text {[42]. }}$

Proline and alanine were the principal amino acids in JPC. Aspartic and glutamic acid were the predominant amino acids in all other fractions analysed, ranging from $3.55\left(\mathrm{AF}_{\mathrm{Ctrl}}\right)$ to $6.51\left(\mathrm{SF}_{\mathrm{Ctrl}}\right)$ and $5.46\left(\mathrm{SF}_{\mathrm{Et}}\right)$ to $8.07\left(\mathrm{AF}_{\mathrm{Et}}\right)$, respectively. The results were consistent with our previous findings [10], where the amino acid profile of the BSFL meal with increasing crude protein content was elucidated. Comparison of the relative percentage of essential amino acid to the total amino acid of WMF BSFL meals (40.39-49.90\%) with soybean $(46.82 \%)$ and fish meal $(48.99 \%)$ demonstrates the ability of BSFL as a high-protein-quality feed ingredient [42]. In dry mode fractionation of BSFL, a full-fat BSFL meal and partially defatted meal are obtainable. In the proposed WMF scheme JPC, solid fraction and aqueous fractions possess a varying concentration of total amino acid content (JPC $>\mathrm{SF}>\mathrm{AF}$ ), proving the versatility of the process to gain BSFL ingredients with improved functionality. The disparity between the crude protein content and total amino acids suggests that the nitrogen-to-protein conversion factor of 5.7 may not be valid for these novel fractions. Digestibility assays on the BSFL fractions obtained by the novel WMF can be the scope of future studies.

\subsection{Antioxidant Potential of Aqueous Fraction BSFL}

The total phenolic content (TPC) or Folin-Ciocalteu reducing capacity (FCRC) of the aqueous extracts was examined. Extracts of $\mathrm{AF}_{\mathrm{Ctrl}}$ and $\mathrm{AF}_{\mathrm{Hg}}$ had similar values 
32 and 35 mg GAE/g DM, respectively, whereas $\mathrm{AF}_{\mathrm{Et}}$ showed higher FCRC (Table 5). Trolox-equivalent antioxidant capacities of the aqueous fraction extracts were determined by measuring the radical scavenging capacities (DPPH and ABTS) and metal chelating activity (FRAP). Data suggest that the AF do possess antioxidant activity, yet they may be less pronounced when compared to conventional feed additives such as butylated hydroxyanisole (BHA) and butylated hydroxytoluene (BHT) in fish oils and ethoxyquin in the fish meal that are fortified during feed formulations to overcome specific undesirable effects [43]. Nonetheless, intrinsic antioxidant activities exhibited by BSFL extracts were comparable to other edible insect species and invertebrates [44].

Table 5. Trolox equivalent antioxidant capacities (TEAC) of BSFL aqueous fractions.

\begin{tabular}{ccccc}
\hline TEAC & FCRC & ABTS & DPPH & FRAP \\
\hline Sample ID/Unit & mg GAE/g DM & & mg TE/g DM & \\
$\mathrm{AF}_{\mathrm{Ctrl}}$ & $32.27 \pm 3.25^{\mathrm{b}}$ & $0.42 \pm 0.01^{\mathrm{b}}$ & $0.16 \pm 0.03^{\mathrm{a}}$ & $0.44 \pm 0.03^{\mathrm{a}}$ \\
$\mathrm{AF}_{\mathrm{Hg}}$ & $34.49 \pm 1.56^{\mathrm{b}}$ & $0.51 \pm 0.02^{\mathrm{b}}$ & $0.12 \pm 0.03^{\mathrm{ab}}$ & $0.45 \pm 0.01^{\mathrm{a}}$ \\
$\mathrm{AF}_{\mathrm{Et}}$ & $55.95 \pm 1.07^{\mathrm{a}}$ & $0.86 \pm 0.09^{\mathrm{a}}$ & $0.08 \pm 0.01^{\mathrm{b}}$ & $0.23 \pm 0.07^{\mathrm{b}}$
\end{tabular}

Results are expressed as means \pm standard deviation. AF-Aqueous fractions; Ctrl-Control; Hg-Homogenization; Et-Enzymatic treatment; GAE — Gallic acid equivalent; TE-Trolox equivalent. Values with a different superscript letter within the column signify statistical difference $(p<0.05)$.

Within the scope of wet mode fractionation, homogenization treatment did not provide any decisive advantage other than inhibiting lipid hydrolysis to an extent in the lipid profile of solid and cream fractions. Enzymatic treatment did impart noticeable improvements to lipid separation and protein quality parameters (PDI and PS) and can be implemented in industrial-scale operations to obtain hydrolysed proteins in the aqueous fraction. Life cycle analysis for a BSF prepupae enzymatic-assisted fractionation procedure with B. licheniformis protease enzyme was found to impact the environment $32 \%$ more than the conventional chemical method [45]. The simple unit operations considered for the proposed WMF process (steam blanching, pulping with juice press and centrifugation) proved sufficient to obtain high-quality BSFL fractions with dynamic properties that can be further dried and provisioned as an alternative to conventional feed ingredients.

The functional properties displayed by BSFL protein makes it an attractive candidate for inclusion in food products, as well. The principal limitation of this process seems to be the lipid hydrolysis in cream and solid fractions; further investigation into this aspect will enable future research to circumvent this problem, thereby making this facile, elegant and low-energy WMF a mainstream process for the production of sustainable feed and food ingredients from BSFL.

The overall material distribution (wet and dry basis) within the wet mode fractionation setup (control treatment) is illustrated in Figure 7. Three proteinaceous streams were obtained, namely juice press cake with $59.1 \%$, solid fraction with $52 \%$ and aqueous fraction with $39.4 \%$ of proteins. Although their protein quality may vary, they can be readily included in different formulations for food, feed and other applications. The chitin distribution in the various product streams emerging from WMF was also estimated. As shown in Figure 7, the juice press cake had $60 \%$ of the total chitin content, whereas the remaining $40 \%$ was found in the solid fraction of the control treatment. A better juice press, treatment with chitinase enzymes or other novel fractionation schemes could be adopted in future studies to valorise the chitin present in BSFL. 


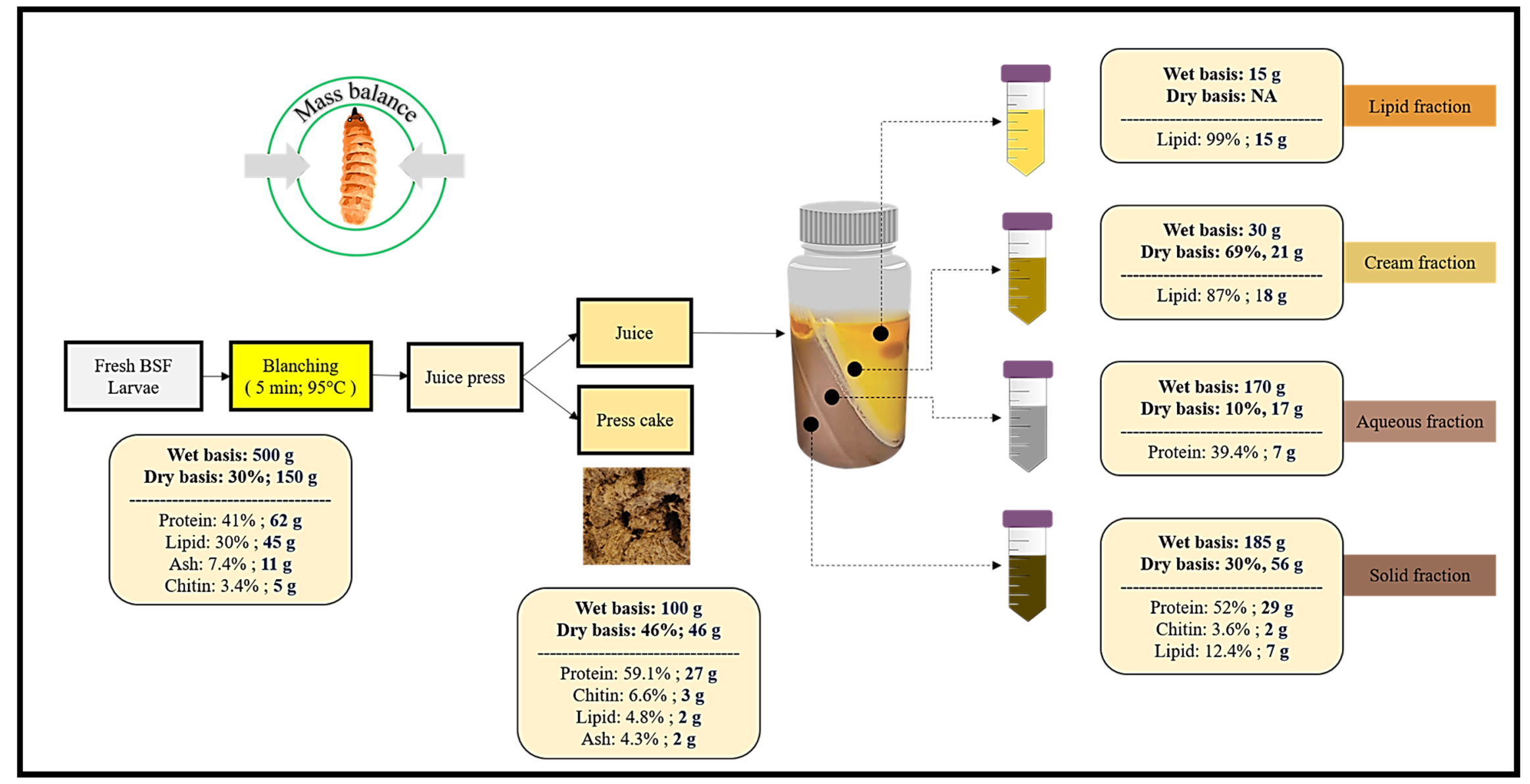

Figure 7. Overall material distribution in the wet mode fractionation process. 


\subsection{Industrial Relevance and Perspectives}

A typical dry fractionation of insect would encompass a drying step, wherein the insect larvae would be dried to eliminate the moisture content, which would account for two-thirds of the fresh weight in case of BSFL, followed by mechanical treatment in a screw press to obtain fat and partially defatted protein meal [24]. Within the scope of dry fractionation, the partially defatted protein meal can be subjected to size reduction and air classification to obtain a protein-enriched fraction and protein-depleted fraction. The key parameters that influence the air classification are particle size, residual lipid content in the defatted flour and chemical composition of the insect flour (fibre content, presence of nonprotein nitrogen, etc.). An interesting study [46] on the biochemical characteristics of supercritical carbon dioxide defatted and air classified cricket and mealworm fractions showed the possibility of protein enrichment in insect flours. Yet, the actual protein content difference between the fine and coarse fractions seems to be less pronounced than anticipated and different from plant proteins [46]. Perhaps wet mode fractionation could be an ideal alternative to the dry mode, as the insect biomass can be pretreated chemically with organic acids [23] or enzymatically with protease or chitinase enzymes to obtain functional ingredients. In addition, emerging novel processing techniques such as high hydrostatic pressure extraction [47], high-pressure homogenization, high-pressure processing, ultrasound, cold plasma [48] and pulsed electric field pretreatment-based insect biorefinery [49] could aid in generating functional ingredients from BSFL.

\section{Conclusions}

The wet mode fractionation is a versatile process to obtain functional ingredients from BSFL and can be pursued by researchers and insect processors. Washing and steam blanching ensures the safety of BSFL as a feed ingredient, eliminating physical, chemical and microbiological hazards. Pulping steam-blanched larvae produces a chitin-rich press cake, and juice, when further centrifuged, gives four distinct fractions with varying functional properties. Homogenization of BSFL juice had a negligible effect or in some cases negatively affected the properties of juice fractions. Enzymatic hydrolysis could be considered depending on the end-use of the BSFL ingredient; for feed, it might enhance the bioavailability of proteins and mitigate allergenicity, whereas the technofunctional properties of hydrolysed proteins were inferior when compared to native proteins in the control treatment. Saturated fatty acids dominated the lipid profile for all fractions. Further investigation on lipid hydrolysis in the cream and solid fractions could shed light on the underlying mechanism involved.

Author Contributions: Conceptualization, M.A.V. and F.C.; validation, M.A.V., F.C., C.G. and C.T.; formal analysis, H.K.R.; writing — original draft preparation, H.K.R.; writing—review and editing, M.A.V., F.C., C.G. and C.T.; supervision, M.A.V., F.C., J.C. and C.T.; project administration, M.A.V., F.C., J.C. and C.T. All authors have read and agreed to the published version of the manuscript.

Funding: This research received no external funding.

Institutional Review Board Statement: Not applicable.

Informed Consent Statement: Not applicable.

Data Availability Statement: The data that support the findings of this study are available upon request from the corresponding author.

Acknowledgments: Harish Karthikeyan Ravi is thankful to Region Sud PACA for the PhD grant.

Conflicts of Interest: The authors declare no conflict of interest. 


\section{References}

1. Tomberlin, J.K.; van Huis, A. Black soldier fly from pest to "crown jewel" of the insects as feed industry: An historical perspective. J. Insects Food Feed 2020, 6, 1-4. [CrossRef]

2. Guo, H.; Jiang, C.; Zhang, Z.; Lu, W.; Wang, H. Material flow analysis and life cycle assessment of food waste bioconversion by black soldier fly larvae (Hermetia illucens L.). Sci. Total Environ. 2021, 750, 141656. [CrossRef]

3. Ravi, H.K.; Degrou, A.; Costil, J.; Trespeuch, C.; Chemat, F.; Vian, M.A. Larvae mediated valorization of industrial, agriculture and food wastes: Biorefinery concept through bioconversion, processes, procedures, and products. Processes 2020, 8, 857. [CrossRef]

4. Jucker, C.; Lupi, D.; Moore, C.D.; Leonardi, M.G.; Savoldelli, S. Nutrient recapture from insect farm waste: Bioconversion with Hermetia illucens (L.) (Diptera: Stratiomyidae). Sustainability 2020, 12, 362. [CrossRef]

5. European Commission. European Union United States is Europe's Main Soya Beans Supplier with Imports Up by 112\%; European Union: Maastricht, The Netherlands, 2019; pp. 28-29.

6. Abd El-Hack, M.E.; Shafi, M.E.; Alghamdi, W.Y.; Abdelnour, S.A.; Shehata, A.M.; Noreldin, A.E.; Ashour, E.A.; Swelum, A.A.; Al-sagan, A.A.; Alkhateeb, M.; et al. Black soldier fly (Hermetia illucens) meal as a promising feed ingredient for poultry: A comprehensive review. Agriculture 2020, 10, 339. [CrossRef]

7. Bessa, L.W.; Pieterse, E.; Marais, J.; Hoffman, L.C. Why for feed and not for human consumption? The black soldier fly larvae. Compr. Rev. Food Sci. Food Saf. 2020, 19, 2747-2763. [CrossRef]

8. Gasco, L.; Biasato, I.; Dabbou, S.; Schiavone, A.; Gai, F. Animals fed insect-based diets: State-of-the-art on digestibility, performance and product quality. Animals 2019, 9, 170. [CrossRef]

9. Turck, D.; Castenmiller, J.; De Henauw, S.; Hirsch-Ernst, K.I.; Kearney, J.; Maciuk, A.; Mangelsdorf, I.; McArdle, H.J.; Naska, A.; Pelaez, C.; et al. Safety of dried yellow mealworm (Tenebrio molitor larva) as a novel food pursuant to Regulation (EU) $2015 / 2283$. EFSA J. 2021, 19, 1-29.

10. Ravi, H.K.; Degrou, A.; Costil, J.; Trespeuch, C.; Chemat, F.; Vian, M.A. Effect of devitalization techniques on the lipid, protein, antioxidant, and chitin fractions of black soldier fly (Hermetia illucens) larvae. Eur. Food Res. Technol. 2020, 246, 2549-2568. [CrossRef]

11. Caligiani, A.; Marseglia, A.; Leni, G.; Baldassarre, S.; Maistrello, L.; Dossena, A.; Sforza, S. Composition of black soldier fly prepupae and systematic approaches for extraction and fractionation of proteins, lipids and chitin. Food Res. Int. 2018, 105, 812-820. [CrossRef] [PubMed]

12. Azzollini, D.; van Iwaarden, A.; Lakemond, C.M.M.; Fogliano, V. Mechanical and enzyme assisted fractionation process for a sustainable production of black soldier fly (Hermetia illucens) ingredients. Front. Sustain. Food Syst. 2020, 4, 1-9. [CrossRef]

13. Smets, R.; Verbinnen, B.; Van De Voorde, I.; Aerts, G.; Claes, J.; Van Der Borght, M. Sequential extraction and characterisation of lipids, proteins, and chitin from black soldier fly (Hermetia illucens) larvae, prepupae, and pupae. Waste Biomass Valorization $\mathbf{2 0 2 0}$ 11, 6455-6466. [CrossRef]

14. Janssen, R.H.; Vincken, J.P.; Van Den Broek, L.A.M.; Fogliano, V.; Lakemond, C.M.M. Nitrogen-to-protein conversion factors for three edible insects: Tenebrio molitor, Alphitobius diaperinus, and Hermetia illucens. J. Agric. Food Chem. 2017, 65, 2275-2278. [CrossRef]

15. Ravi, H.K.; Breil, C.; Vian, M.A.; Chemat, F.; Venskutonis, P.R. Biorefining of bilberry (Vaccinium myrtillus L.) pomace using microwave hydrodiffusion and gravity, ultrasound-assisted, and bead-milling extraction. ACS Sustain. Chem. Eng. 2018, 6, 4185-4193. [CrossRef]

16. Gharby, S.; Ravi, H.K.; Guillaume, D.; Abert Vian, M.; Chemat, F.; Charrouf, Z. 2-methyloxolane as alternative solvent for lipid extraction and its effect on the cactus (Opuntia ficus-indica L.) seed oil fractions. OCL 2020, 27, 27. [CrossRef]

17. Van Eys, J.E. Manual of Quality Analyses for Soybean Products in the Feed Industry, 2nd ed.; U.S. Soybean Export Council: Singapore, 2012.

18. Batish, I.; Brits, D.; Valencia, P.; Miyai, C.; Rafeeq, S.; Xu, Y.; Galanopoulos, M.; Sismour, E.; Ovissipour, R. Effects of enzymatic hydrolysis on the functional properties, antioxidant activity and protein structure of black soldier fly (Hermetia illucens) protein. Insects 2020, 11, 876. [CrossRef]

19. Singleton, V.L.; Rossi, J.A. Colorimetry of total phenolics with phosphomolybdic-phosphotungstic acid reagents. Am. J. Enol. Vitic. 1965, 16, 144-158.

20. Brand-Williams, W.; Cuvelier, M.E.; Berset, C. Use of a free radical method to evaluate antioxidant activity. LWT Food Sci. Technol. 1995, 28, 25-30. [CrossRef]

21. Re, R.; Pellegrini, N.; Proteggente, A.; Pannala, A.; Yang, M.; Rice-Evans, C. Antioxidant activity applying an improved ABTS radical cation decolorization assay. Free Radic. Biol. Med. 1999, 26, 1231-1237. [CrossRef]

22. Benzie, I.F.; Strain, J.J. The ferric reducing ability of plasma (FRAP) as a measure of "antioxidant power": The FRAP assay. Anal. Biochem. 1996, 239, 70-76. [CrossRef]

23. Soetemans, L.; Uyttebroek, M.; D'Hondt, E.; Bastiaens, L. Use of organic acids to improve fractionation of the black soldier fly larvae juice into lipid- and protein-enriched fractions. Eur. Food Res. Technol. 2019, 245, 2257-2267. [CrossRef]

24. Matthäus, B.; Piofczyk, T.; Katz, H.; Pudel, F. Renewable resources from insects: Exploitation, properties, and refining of fat obtained by cold-pressing from Hermetia illucens (Black Soldier Fly) larvae. Eur. J. Lipid Sci. Technol. 2019, 121, 1-11. [CrossRef]

25. Bertrand, H.; Frédéric, F.; Joachim, C.; Lucien, M.; Christophe, B.; Giorgia, P.; Megido Rudy, C. w3-enrichment of Hermetia illucens (L. 1758) prepupae from oilseed byproducts. J. Saudi Soc. Agric. Sci. 2021, 20, 155-163. 
26. Xu, X.; Ji, H.; Belghit, I.; Liland, N.S.; Wu, W.; Li, X. Effects of black soldier fly oil rich in n-3 HUFA on growth performance, metabolism and health response of juvenile mirror carp (Cyprinus carpio var. specularis). Aquaculture 2021, 533, 736144. [CrossRef]

27. Caligiani, A.; Marseglia, A.; Sorci, A.; Bonzanini, F.; Lolli, V.; Maistrello, L.; Sforza, S. Influence of the killing method of the black soldier fly on its lipid composition. Food Res. Int. 2018, 116, 276-282. [CrossRef] [PubMed]

28. Ravi, H.K.; Vian, M.A.; Tao, Y.; Degrou, A.; Costil, J.; Trespeuch, C.; Chemat, F. Alternative solvents for lipid extraction and their effect on protein quality in black soldier fly (Hermetia illucens) larvae. J. Clean. Prod. 2019, 238, 117861. [CrossRef]

29. Smets, R.; Goos, P.; Claes, J.; Van Der Borght, M. Optimisation of the lipid extraction of fresh black soldier fly larvae (Hermetia illucens) with 2-methyltetrahydrofuran by response surface methodology. Sep. Purif. Technol. 2021, 258, 118040. [CrossRef]

30. Wang, T.; Shen, Q.; Feng, W.; Wang, C.; Yang, F. Aqueous ethyl acetate as a novel solvent for the degreasing of black soldier fly (Hermetia illucens L.) larvae: Degreasing rate, nutritional value evaluation of the degreased meal, and thermal properties. J. Sci. Food Agric. 2020, 100, 1204-1212. [CrossRef] [PubMed]

31. Ishak, S.; Kamari, A.; Yusoff, S.N.M.; Halim, A.L.A. Optimisation of biodiesel production of black soldier fly larvae rearing on restaurant kitchen waste. J. Phys. Conf. Ser. 2018, 1097, 012052. [CrossRef]

32. Bußler, S.; Rumpold, B.A.; Jander, E.; Rawel, H.M.; Schlüter, O.K. Recovery and techno-functionality of flours and proteins from two edible insect species: Meal worm (Tenebrio molitor) and black soldier fly (Hermetia illucens) larvae. Heliyon 2016, 2, e00218. [CrossRef] [PubMed]

33. Rabani, V.; Cheatsazan, H.; Davani, S. Proteomics and lipidomics of black soldier fly (Diptera: Stratiomyidae) and blow fly (Diptera: Calliphoridae) larvae. J. Insect Sci. 2019, 19, 29. [CrossRef] [PubMed]

34. Miron, L.T.; Postma, R.P.; Bosch, G.; Eppink, M.H.M. Preliminary evaluation of aqueous protein extraction from black soldier fly larvae (Hermetia illucens L.). Ind. Biotechnol. 2019, 15, 365-369. [CrossRef]

35. Leni, G.; Tedeschi, T.; Faccini, A.; Pratesi, F.; Folli, C.; Puxeddu, I.; Migliorini, P.; Gianotten, N.; Jacobs, J.; Depraetere, S. Shotgun proteomics, in-silico evaluation and immunoblotting assays for allergenicity assessment of lesser mealworm, black soldier fly and their protein hydrolysates. Sci. Rep. 2020, 10, 1-10. [CrossRef] [PubMed]

36. Li, C.; Yang, J.; Yao, L.; Qin, F.; Hou, G.; Chen, B.; Jin, L.; Deng, J.; Shen, Y. Characterisation, physicochemical and functional properties of protein isolates from Amygdalus pedunculata Pall seeds. Food Chem. 2020, 311, 125888. [CrossRef]

37. Purschke, B.; Meinlschmidt, P.; Horn, C.; Rieder, O.; Jäger, H. Improvement of techno-functional properties of edible insect protein from migratory locust by enzymatic hydrolysis. Eur. Food Res. Technol. 2018, 244, 999-1013. [CrossRef]

38. Zielińska, E.; Karaś, M.; Baraniak, B. Comparison of functional properties of edible insects and protein preparations thereof. LWT Food Sci. Technol. 2018, 91, 168-174. [CrossRef]

39. Hall, F.G.; Jones, O.G.; O’Haire, M.E.; Liceaga, A.M. Functional properties of tropical banded cricket (Gryllodes sigillatus) protein hydrolysates. Food Chem. 2017, 224, 414-422. [CrossRef]

40. Yi, L.; Lakemond, C.M.; Sagis, L.M.; Eisner-Schadler, V.; van Huis, A.; van Boekel, M.A. Extraction and characterisation of protein fractions from five insect species. Food Chem. 2013, 141, 3341-3348. [CrossRef]

41. Gravel, A.; Doyen, A. The use of edible insect proteins in food: Challenges and issues related to their functional properties. Innov. Food Sci. Emerg. Technol. 2020, 59, 102272. [CrossRef]

42. Kim, E.J.; Utterback, P.L.; Parsons, C.M. Comparison of amino acid digestibility coefficients for soybean meal, canola meal, fish meal, and meat and bone meal among 3 different bioassays. Poult. Sci. 2012, 91, 1350-1355. [CrossRef]

43. Hamre, K.; Kolås, K.; Sandnes, K. Protection of fish feed, made directly from marine raw materials, with natural antioxidants. Food Chem. 2010, 119, 270-278. [CrossRef]

44. Di Mattia, C.; Battista, N.; Sacchetti, G.; Serafini, M. Antioxidant activities in vitro of water and liposoluble extracts obtained by different species of edible insects and invertebrates. Front. Nutr. 2019, 6, 1-7. [CrossRef] [PubMed]

45. Rosa, R.; Spinelli, R.; Neri, P.; Pini, M.; Barbi, S.; Montorsi, M.; Maistrello, L.; Marseglia, A.; Caligiani, A.; Ferrari, A.M. Life cycle assessment of chemical vs. enzymatic-assisted extraction of proteins from black soldier fly prepupae for the preparation of biomaterials for potential agricultural use. ACS Sustain. Chem. Eng. 2020, 8, 14752-14764. [CrossRef]

46. Sipponen, M.H.; Mäkinen, O.E.; Rommi, K.; Heiniö, R.L.; Holopainen-Mantila, U.; Hokkanen, S.; Hakala, T.K.; Nordlund, E. Biochemical and sensory characteristics of the cricket and mealworm fractions from supercritical carbon dioxide extraction and air classification. Eur. Food Res. Technol. 2018, 244, 19-29. [CrossRef]

47. Bolat, B.; Ugur, A.E.; Oztop, M.H.; Alpas, H. Effects of high hydrostatic pressure assisted degreasing on the technological properties of insect powders obtained from Acheta domesticus \& Tenebrio molitor. J. Food Eng. 2021, 292, 110359.

48. Ojha, S.; Bußler, S.; Psarianos, M.; Rossi, G.; Schlüter, O.K. Edible insect processing pathways and implementation of emerging technologies. J. Insects Food Feed 2021, 7, 877-900. [CrossRef]

49. Alles, M.C.; Smetana, S.; Parniakov, O.; Shorstkii, I.; Toepfl, S.; Aganovic, K.; Heinz, V. Bio-refinery of insects with Pulsed electric field pre-treatment. Innov. Food Sci. Emerg. Technol. 2020, 64, 120403. [CrossRef] 